\title{
THE INFLUENCE OF DIFFERENT POT STILL TYPE ON QUALITY OF WILLIAMS PEAR DISTILLATES
}

\author{
Borislav Miličević, Jurislav Babić, Radoslav Miličević, Drago Šubarić
}

Original scientific paper Pear brandy is one of the most desirable alcoholic beverages across Europe. But of all varieties, the most appreciated is Bartlett pear or Williams's pear as it is better known. The purpose of this work was to create an objective evaluation of the influence of various construction forms of pot still, (alembic, pot and spheric) on final quality of Williams pear brandy. Gas-chromatography and sensory analysis were applied to the determination of quality and aroma profile of Williams pear brandy. Results showed that the type of pot still construction has a significant influence on quality and aroma profile of Williams pear brandy. The samples that are produced by alambic pot still had better quality and more expressive flavour. The best evaluated sample had an amount of ethanol of $59,51 \%$ in total volume, esters $478 \mathrm{mg} / 1$, aldehydes $120 \mathrm{mg} / \mathrm{l}$ and higher alcohols of $962 \mathrm{mg} / 1$.

Keywords: pot still; quality; Williams pear distillate

Utjecaj različitih tipova uređaja za destilaciju na kvalitetu rakije od kruške Viljamovke

Izvorni znanstveni članak Jedno od najpoželjnijih alkoholnih pića diljem Europe je rakija od kruške. Od svih vrsta kruške, najznačajnija je sorta Bartlett ili Viljamovka. Cilj rada bio je istražiti utjecaj različitih tipova konstrukcijskih uređaja za destilaciju (alembic, pot and spheric) na kvalitetu rakije od kruške sorte Viljamovka. Pri određivanju kvalitete i arome uzoraka rakija Viljamovki korištene su senzorske analize te plinska kromatografija. Rezultati su pokazali da konstrukcija uređaja za destilaciju ima značajan utjecaj na kvalitetu i aromu rakije Viljamovke. Uzorci destilirani na uređaju tipa alembic imali su najbolje ocijenjenu kvalitetu i aromu. Najbolje ocijenjeni uzorak sadržavao je 59,51 \% etanola, $478 \mathrm{mg} / \mathrm{l}$ estera, $120 \mathrm{mg} / \mathrm{l}$ aldehida te $962 \mathrm{mg} / \mathrm{l}$ viših alkohola.

Ključne riječi: kvaliteta; rakija od kruške Viljamovke; uređaj za destilaciju

\section{Introduction}

Pear is one of the widely grown fruit species across the world and it is considered to be one of the oldest grown species. The earliest written documents on its growing date back to the New Stone Age i.e. over 20,000 years and it is thought that 6000 varieties have been developed to date [1]. But of all varieties, the most appreciated is Williams's pear or Bartlett pear. It is the most widespread pear variety of all [2]. William's pears are probably best expressed through the famous William's pear brandy.

Production of William's pear brandy starts with alcoholic fermentation of fully ripe fruits which should be conducted slowly at low temperature, most suitably at $18^{\circ} \mathrm{C}$, so that valuable aromatics of fruit are preserved as much as possible. Distillation of fermented crushed fruit should be done within $48 \mathrm{~h}$ after fermentation is finished, so that harmful components do not increase (acids, methanol, esters, aldehydes, HCN etc.) and accumulated secondary aroma does not become lost. Distillation could be performed in a different type of pot still. William's pear distillate never matures (ages) in a cask because primary distillate components are incompatible with secondary components extracted from a wooden container. After it has been processed (and distillate is diluted to its ultimate strength from $40 \div 45 \%$ vol.), Williams pear brandy is consumed colourless and cooled at $12 \div 15^{\circ} \mathrm{C}$ [2]

Quality of alcoholic beverages is influenced by many factors, mainly by quality of starting raw material and production process [3]. Over past years investigations focus was on alcoholic fermentation and distillation procedure, as the most important stages of the

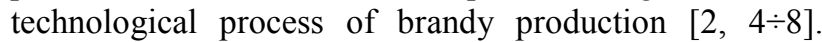

Miličević [9] investigated influence of fermentation process with immobilized yeast cells on final quality of tangerine distillates. The obtained results have shown that fermentation with immobilized yeast cells has significant influence on aroma and quality of distillates. Fermentation time was reduced and final distillates had satisfactory sensory and analytical profiles. Nikićević [2] suggests adding suitable pectolitic enzyme and appropriate yeast strain throughout fermentation to disintegrate Bartlett pear fruits and to reduce boiling medium $\mathrm{pH}$.

Volatile aromatic compounds are the most important for the quality of brandies [10]. These compounds can be divided into four groups: primary, which derive from fruit varieties; secondary, which develop during the fermentation processes; tertiary substances, which develop during the distillation process; quaternary substances, which develop during the maturing process. The most important volatile compounds present in the distillate come from microbial fermentation and belong to the chemical classes of higher alcohols, esters and aldehydes [11].

The aim of this work was to investigate influence of various types of pot still (alembic, pot and spherical) on quality of Williams pear brandy.

\section{Materials and methods}

Each set of samples of fermented Williams pear pulp $(100 \mathrm{~L})$ is taken from the production process at "Zvečevo d.d. Food Industry", from the harvest of the year 2011. All samples were protected by $\mathrm{SO}_{2}(30 \mathrm{mg} / \mathrm{l})$.

Fermentation was carried out by selected yeast Feromol-Bouqet 125 in internal loop gas-lift fermenter and controlled thermal regime using outer refrigeration of 
fermenter with running water and keeping the average temperature in intervals of $18 \div 20{ }^{\circ} \mathrm{C}$. The average duration of fermentation process under these conditions was 19 days for each set.
Williams's pear brandy samples were distilled by three different types of pot still provided by Strix d.o.o. Zagreb according to the distillation protocol described by Nikićević [2]. Pot still types (Fig. 1): Pot still-alembic (PSA), pot still-pot (PSP) and pot still-spherical (PSS).
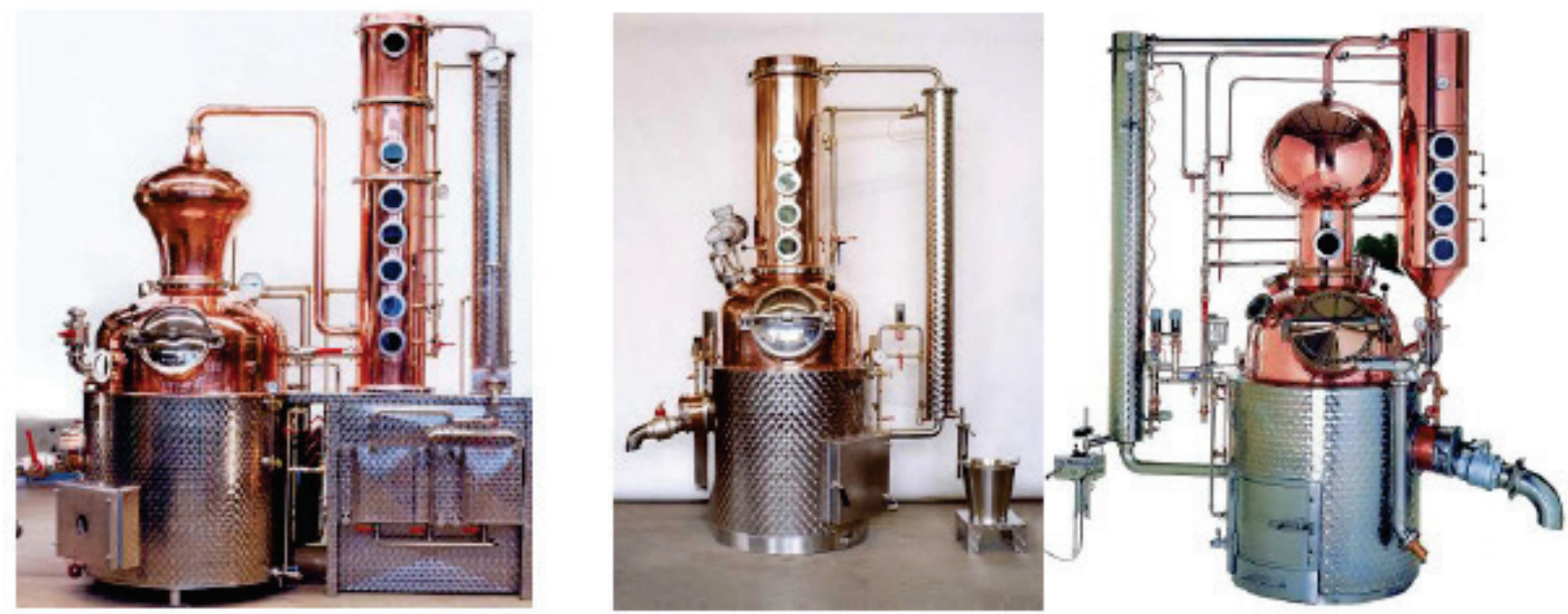

Figure 1 Pot stills used for distillation of William pear brandies: pot still-alembic (PSA), pot still-pot (PSP) and pot still-spherical (PSS)
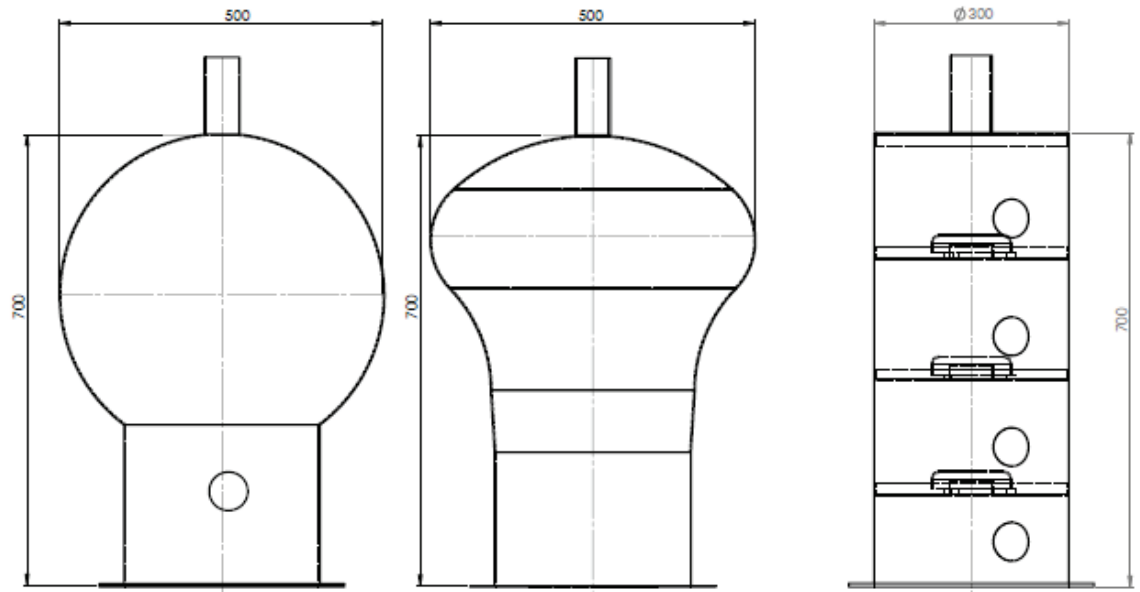

Figure 2 Copper clip distillation devices with various construction forms of still-tops (spherical, alembic and pot)

\subsection{Sensory analyses}

A sensory analysis of samples was performed according to the method of positive scoring factor according to the German DLG model [12].

This model was based on 4 sensorial experiences, which are marked with grades 0 to 5 , including 0 , while the average grade is multiplied by the significance factor. Sensory assessment was conducted in two repetition cycles. Each group had ten testers, selected by selection procedure [13].

\subsection{Chemical analysis of distillates}

Standard analytical techniques were applied for the evaluation of the distillates quality. In industrial control laboratories these techniques represent the basis for the determination of the quality parameters. Chemical analysis of the distillates carried out: ethanol, total extract, total acidity, total $\mathrm{SO}_{2}$, total aldehydes, total esters, higher alcohols, furfural and methanol analysis [14, 15, 16].

\subsection{Analyses of aroma substances}

The major volatile components were analyzed on the basis of the European Community Reference Methods for the analysis of spirits using gas chromatography $[15,16]$.

Gas chromatography (GC) analyses were performed on a Chrompack 437A gas chromatograph with a split /splitless injector and a FID detector. For analysis of distillates a Chrompack Poraplot capillary column $(25 \mathrm{~m} \times 0,25 \mu \mathrm{m}$ i.d. $0,25 \mu \mathrm{m})$ was used. Initial oven temperature was kept at $35^{\circ} \mathrm{C}$ for $7 \mathrm{~min}$, then raised at $10{ }^{\circ} \mathrm{C} / \mathrm{min}$ to $80{ }^{\circ} \mathrm{C}$ followed by $25{ }^{\circ} \mathrm{C} / \mathrm{min}$ to $180{ }^{\circ} \mathrm{C}$, and kept for $4 \mathrm{~min}$ at $180{ }^{\circ} \mathrm{C}$. Qualitative analysis was done by comparing the standard retention times (analytical grade from Merck, Germany) with the corresponding peaks of samples. The quantification was carried out by comparing the peak areas to those of the Merck standards. 


\section{Results and discussion 3.1 Sensory analyses}

Tab. 1 shows the results of sensor analyses of distillates. Sensory assessment of samples was carried out according to the method of positive scoring with weight factors 3 to 9, according to German $D L G$ model [12]. The scoring was performed by a group of ten professional testers with extensive experience in sensory assessment of distillates. Average score of all assessed brandies was relatively high. It was the result of quality fully ripe pears, implemented method of fermentation process and distillation technique.
Total sensory assessment ranged in the interval $70,30 \div 98,50$, which indicates significant differences among samples. Furthermore, they can be addressed to different construction forms of pot still, since other factors in the production of distillates were the same for all samples. The William pear brandy produced by pot still-alembic had the best sensory properties $(98,5$ points of 100) characterised by pleasant aroma without sharp alcoholic odour tones. PSP sample had slightly lower sensory quality $(96,1)$. On the other hand, PSS sample was significantly lower evaluated $(70,3)$ in comparison to PSA and PSP.

Table 1 Sensory analysis results of Williams pear brandies. Samples were produced by different pot still types.

\begin{tabular}{|c|c|c|c|c|c|}
\hline \multirow{2}{*}{ Sample } & \multicolumn{4}{|c|}{ Assessment characteristics } & $\begin{array}{c}\text { TOTAL } \\
(\max 100 \text { points })\end{array}$ \\
\cline { 2 - 6 } & $\begin{array}{c}\text { Colour } \\
(\max 15 \text { points })\end{array}$ & $\begin{array}{c}\text { Clearness } \\
(\max 15 \text { points })\end{array}$ & $\begin{array}{c}\text { Odour } \\
(\max 25 \text { points })\end{array}$ & $\begin{array}{c}\text { Tax } \\
(\max 45 \text { points })\end{array}$ & 44,00 \\
\hline PSA & 15,00 & 15,00 & 24,50 & 43,20 & 98,50 \\
\hline PSP & 14,70 & 14,70 & 23,50 & 26,00 & 96,10 \\
\hline PSS & 14,40 & 14,40 & 15,50 & 70,30 \\
\hline
\end{tabular}

Pot still-alembic (PSA), pot still-pot (PSP) and pot still-spherical (PSS)

\subsection{Chemical analyses}

Tab. 2 shows the chemical composition of Williams pear brandies. Chemical composition of Williams pear brandies were within referential values $[16,17,18]$.

Table 2 Chemical composition of Williams pear brandies produced by

\begin{tabular}{|l|c|c|c|}
\multicolumn{4}{|c|}{ different pot still types } \\
\hline Ethanol (\% vol.) & PSA & PSP & PSS \\
\hline Total extract (g/ L) & 59,51 & 59,60 & 51,50 \\
\hline Total $\mathrm{SO}_{2}$ (mg/L) & 0,944 & 0,834 & 0,914 \\
\hline Total acidity (mg/L) & 4,54 & 3,95 & 3,85 \\
\hline Aldehydes (mg/L a.a.) & 247,60 & 285,00 & 284,20 \\
\hline Esters (mg/L a.a.) & 120,00 & 105,00 & 107,00 \\
\hline Higher alc. (mg/L a.a.) & 478,23 & 428,23 & 390,00 \\
\hline Furfural (mg/L a.a.) & 962,14 & 930,71 & 980,27 \\
\hline Methanol (mg/L a.a.) & 0,002 & 0,001 & - \\
\hline Pot still-almbic (PS), pot stillpot & 0,02 & 0,03 & - \\
\hline
\end{tabular}

\begin{tabular}{lccc} 
Pot still-alembic (PSA), pot still-pot (PSP) and pot still-spherical (PSS) \\
\hline
\end{tabular}

The results showed that brandies had ethanol content of 51,50 (PSS), 59,51 (PSA) and 59,60\% (PSP) which is within referential values $[2,19]$. The amount of ethanol corresponds to the requirements on quality of brandies. Lower content of alcohol may cause the reduction of some aroma substance in brandies [20].

The content of total extract in all samples was within the recommended values [19] and was in range $0.834-$ $0.944 \mathrm{~g} / \mathrm{L}$.

The presence of free $\mathrm{SO}_{2}$ in distillates (3.85 to 4.54 $\mathrm{mg} / \mathrm{L})$ is the result of added $\mathrm{SO}_{2}$ prior fermentation which is important for the protection of pulp from no controlled fermentation process and oxidation. Free $\mathrm{SO}_{2}$ may bind acetaldehyde which develops during distillation.

Aldehydes were in range $107,00 \div 120,00 \mathrm{mg} / \mathrm{L}$ and higher alcohols 930,71 $\div 980,27 \mathrm{mg} / \mathrm{L}$. PSA had significantly higher amount of aldehydes $(120 \mathrm{mg} / \mathrm{L})$ in comparison to PSP (105 mg/L) and PSS (107 mg/L). During maturation of distillates the content of aldehydes and higher alcohols may cause formation of higher quantity of acetals [21, 22]
Among all samples, PSP had the lowest content of aldehydes $(105 \mathrm{mg} / \mathrm{L})$ and higher alcohols $(930,71 \mathrm{mg} / \mathrm{L})$.

PSA had the lowest total acidity $(247,6 \mathrm{mg} / \mathrm{L})$ but the highest content of esters $(478,23 \mathrm{mg} / \mathrm{L})$.

Methanol and furfural in all brandies were in insignificant amount or not detected.

Volatile aromatic compounds are the most important for the quality of brandies [10]. Tab. 3 presents the content of important aroma substances of analyzed William pear brandies.

Table 3 Content of aroma compounds of Williams pear brandies. $(\mathrm{mg} / \mathrm{L})$ produced by different pot still types.

\begin{tabular}{|c|c|c|c|}
\hline $\begin{array}{c}\text { Aroma }(\mathrm{mg} / \mathrm{L}) \\
\text { compounds }\end{array}$ & PSA & PSP & PSS \\
\hline Acetaldehyde & 43,76 & 43,96 & 44,11 \\
\hline Methanol & 0,025 , & 0,038 & n.i. \\
\hline 1-Propanol & 94,75 & 84,70 & 88,20 \\
\hline N-Hexanol & 17,16 & 19,18 & 18,35 \\
\hline 2-Phenyl Ethanol & 22,97 & 23,52 & 23,45 \\
\hline Isobutyl Alcohol & 23,62 & 19,39 & 15,37 \\
\hline Isoamyl Alcohol & 118,79 & 119,91 & 98,80 \\
\hline Ethyl Acetate & 56,57 & 54,20 & 44,31 \\
\hline Ethyl Hexanoate & 12,47 & 11,57 & n.i. \\
\hline Ethyl Lactate & 3,07 & 1,41 & n.i. \\
\hline Ethyl Octanoate & 35,92 & 32,69 & 32,92 \\
\hline $\begin{array}{l}\text { Methyl 2-Trans, 4-Cis } \\
\text { Decadieonate }\end{array}$ & 52,16 & 53,18 & 52,24 \\
\hline $\begin{array}{l}\text { Ethyl 2-Trans, 4-Cis } \\
\text { Decadieonate }\end{array}$ & 65,34 & 64,325 & 57,49 \\
\hline Ethyl Decanoate & 31,74 & 30,91 & 29,18 \\
\hline Ethyl Dodecanoate & 16,23 & 15,73 & 14,16 \\
\hline Ethyl,Cis-4 Decanoate & 11,07 & 10,08 & 10,13 \\
\hline Ethylpentadecanoate & 9,78 & 9,54 & 9,65 \\
\hline Ethyl Caprate & 8,23 & 9,56 & 10,12 \\
\hline A-Terpineol & 4,1 & 4,78 & 3,17 \\
\hline Terpinen-4-O1 & 4,01 & 4,02 & 3,45 \\
\hline Linalool & 0,63 & 0,87 & 1,33 \\
\hline
\end{tabular}

n.i. - not identified; Pot still-alembic (PSA), pot still-pot (PSP) and pot still-spherical (PSS)

The most abundant aromatic compound in all samples was isoamyl alcohol $98,80 \div 119,90 \mathrm{mg} / \mathrm{L}$ (higher 
alcohol) followed by esters: methyl 2-trans, 4-cis decadieonate $(52,16 \div 53,18 \mathrm{mg} / \mathrm{L})$ and ethyl 2-trans, 4 cis decadieonate $(57,49 \div 65,34 \mathrm{mg} / \mathrm{L})$. PSA and PSP had almost the same quantity of isoamyl alcohol (118,79 and $119,91 \mathrm{mg} / \mathrm{L}$ ) while PSS had significantly lower amount of $98,8 \mathrm{mg} / \mathrm{L}$. Content of esters had the same trend (higher in PSA and PSP and significantly lower in PSS).

Ethyl ester of octanoic acid was present in a relatively high amount $(32,92 \div 35,92 \mathrm{mg} / \mathrm{L})$ as well as ethyl ester of decanoic acid $(29,18 \div 31,74 \mathrm{mg} / \mathrm{L})$. Ethyl ester of dodecanoic acid was in range $14,16 \div 16,23 \mathrm{mg} / \mathrm{L}$, which corresponds to previous investigation of Ferreira da Silva et al. [23].

Other aroma compounds were in significantly lower amounts (ethyl lactate, n-hexanol, ethyl hexanoate, phenyl ethyl alcohol, ethyl, cis-4 decanoate, ethylpentadecanoate and ethyl caprate).

Results clearly demonstrated that the type of construction forms of pot still significantly affected content and ratio of primary aroma compounds.

Off-flavours components, $\alpha$-terpineol and terpinen-4-ol were in insignificant amount $(3,17 \div 4,1 \alpha$-terpineol and $3,45 \div 4,02 \mathrm{mg} / \mathrm{L}$ for terpinen-4-ol).

Production process pot still-alambic may be highlighted as potentially the best procedure for production of quality Williams pear brandies.

\section{Conclusion}

The obtained results have shown that the type of construction forms of distillery pot still has a significant influence on quality of Williams pear distillates. Moreover, the aroma compounds that mostly contribute to the typical flavour of the Williams pear distillates, such as ethyl 2-trans, 4-cis decadieonate, methyl 2-trans, 4-cis decadieonate, isoamyl alcohol 2-phenylethyl ethanol, are affected by the construction forms of pot still.

Results clearly demonstrated that the type of construction forms of pot still significantly affected content and ratio of primary aroma compounds. The samples produced by distillation with alembic pot still had the best quality among all produced samples characterised by pleasant aroma without sharp alcoholic odour tones.

\section{$5 \quad$ References}

[1] Jules, J. The Pear in History, Literature, Popular Culture, and Art. // Classic Papers in Horticultural Science. The Blackburn Press UK, 2000. pp. 404.

[2] Nikićević, N. Effects of some production factors on chemical composition and sensory qualities of Williams pear brandy. // Journal of Agricultural Sciences. 50, 2(2005), pp. 193-206.

[3] Miličević, B.; Lukić, I.; Babić, J.; Šubarić, D.; Miličević, R.; Ačkar, Đ.; Miličević, D. Aroma and sensory characteristisc of Slavonian plum brandy. // Technologica acta. 5(2012), pp. 1-8

[4] Soufleros, E. H.; Mygdalia, S. A.; Natskoulis, P. Production process and characterization of the traditional Greek fruit distillate "Koumaro" by aromatic and mineral composition. // J. Food Comp. Anal. 18(2005), pp. 699-716. DOl: 10.1016/j.jfca.2004.06.010

[5] Lilly, M.; Lambrechts, M. G.; Pretorius I. S. Effect of Increased Yeast Alcohol Acetyltransferase: Activity on Flavor Profiles of Wine and Distillates. // Apl. Environ.
Microbiol. 2(2000), pp. 744-753. DOI: 10.1128/AEM.66.2.744753.2000

[6] Hernández-Gómez, L. F.; Úbeda-Iranzo, J.; GarcíaRomero, E.; Briones-Pérez A. Comparative production of different melon distillates: Chemical and sensory analyses. // Food Chem. 90(2005). pp. 115-125. DOI: 10.1016/j.foodchem.2004.03.033

[7] Diéguez, S. C.; de la Pe-a, M. L. G.; Gómez, E. F. Volatile composition and sensory characters of commercial Galician Orujo Spirits. // J. Agric. Food Chem. 53(2005), pp. 67596765. DOI: 10.1021/jf040467j

[8] Apostolopoulou, A. A.; Flouros, A.I.; Demertzis, P.G.; Akrida-Demertzi K. Differences in concentration of principal volatile constituents in traditional Greek distillates. // Food Control. 16(2005), pp. 157-164. DOI: 10.1016/j.foodcont.2004.01.005

[9] Miličević, B.; Lukić, I.; Babić, J.; Šubarić, D.; Miličević, R.; Ačkar, Đ. The influence of fermentation process with immobilized yeast cells on quality of tangarine distillates. // Glasnik zaštite bilja. 5(2012), pp. 68-75.

[10] Miličević, B.; Banović, M.; Kovačević Ganić, K.; Gracin, L. Impact of Grape Varieties on Wine Distillates Flavour. // Food technology and biotechnology. 40, 3(2002), pp. 227 232.

[11] Verstrepen, K. J.; Derdelinckx, G.; Dufour, J. P.; Winderickx, J.; Thevelein, J. M.; Pretorius, I. S.; Delvaux, F. R. Flavor-active esters: adding fruitiness to beer. // Journal of Bioscience and Bioengineering. 96(2003), pp. 110-118. DOI: 10.1016/S1389-1723(03)90112-5

[12] Koch, J. Getränkebeurteilung. Eugen Ulmer GmbH Co., Stuttgart, 1986. p. 95-96.

[13] Jellinek G. Sensory Evaluation of Food, Theory and Practice, Ellis Horwod international publishers in since and technology, Chichester 1985, pp. 252-255.

[14] AOAC. Official Methods of Analysis. Association of Official Chemists, Arlington, VA, USA, 1995.

[15] EEC. Council Regulation 2870/00 laying down Community reference methods for the analysis of spirit drinks, Off. J. Eur. Comm. L333, 2000.

[16] EEC. Council Regulation 110/2008 on the definition, description and presentation of spirit drinks, Off. J. Eur. Commun. L39, 2008.

[17] Walton, S.; Glover, B. The ultimate encyclopedia of wine, beer, spirits \& liqueurs. Hermes House, London, 2006.

[18] Walton, S. The connoisseur's guide to Spirits \& Liqueurs. Apple Press, London, 2007.

[19] Nykanen, L.; Suomalainen, H. Aroma of Beer, Wine and Distilled Alcoholic Beverages, Akademie verlag, Berlin, 1983

[20] Conner, J. M.; Birkmyre, L.; Paterson, A.; Piggot, J. R. Headspace concentrations of ethyl esters at different alcoholic strengths. // J. Sci. Food Agric. 77(1998) pp. 121126. DOI: $10.1002 /(\mathrm{SICl}) 1097-0010(199805) 77: 1<121:: \mathrm{AID}$ JSFA14>3.0.CO;2-V

[21] Williams, P. J.; Piggot, J. R. The Effect of Distillation on Grape Flavour, Ellis Horwod Limited, Chichester, 1983.

[22] Guan, S. H.; Pieper, H. J. Examination of the distillation characteristics of the distillate from numerous fruit mashes using GC analysis. // Deut Lebensm Rundsch. 11(1998), pp. 365-374.

[23] Ferreira da Silva, S. C.; Rodrigues, J.; Bertsch, K. Ethyl esters of long chain fatty acids in Brandy: Rapid determination and stability tests. // Eux-de-vie 2007, 2nd International Symposium on Traditional Spirits of Viticultural Origin, Bordeaux, France, 2007. 


\section{Authors' addresses}

Borislav Miličević, PhD, assistant professor Josip Juraj Strossmayer University of Osijek, Faculty of Food Technology Osijek

F. Kuhača 20, 31000 Osijek, Croatia

E-mail: borislav.milicevic@ptfos.hr

Jurislav Babić, PhD, assistant professor

Josip Juraj Strossmayer University of Osijek, Faculty of Food Technology Osijek

F. Kuhača 20, 31000 Osijek, Croatia

E-mail: jbabic@ptfos.hr

Radoslav Miličević, PhD,

University of Tuzla

Univeritetska 8, 75000 Tuzla, BiH

E-mail: radoslavmilicevic@hotmail.com

Drago Šubarić, PhD, full professor

Josip Juraj Strossmayer University of Osijek,

Faculty of Food Technology Osijek

F. Kuhača 20,31000 Osijek, Croatia

E-mail: dsubaric@ptfos.hr 